\title{
Risk and prognosis of ovarian cancer in women with endometriosis: a meta-analysis
}

\author{
H S Kim ${ }^{1}$, T H Kim ${ }^{1}$, H H Chung ${ }^{1}$ and Y S Song ${ }^{\star, 1,2,3}$ \\ ${ }^{1}$ Department of Obstetrics and Gynecology, Seoul National University College of Medicine, 101 Daekak-ro Jongno-gu, Seoul \\ 110-744, Republic of Korea; ${ }^{2}$ Cancer Research Institute, Seoul National University College of Medicine, Seoul 110-799, Republic \\ of Korea and ${ }^{3}$ Major in Biomodulation, World Class University, Seoul National University, Seoul 151-742, Republic of Korea
}

Background: The risk and prognosis of ovarian cancer have not been well established in women with endometriosis. Thus, we investigated the impact of endometriosis on the risk and prognosis for ovarian cancer, and evaluated clinicopathologic characteristics of endometriosis-associated ovarian cancer (EAOC) in comparison with non-EAOC.

Methods: After we searched an electronic search to identify relevant studies published online between January 1990 and December 2012, we found 20 case-control and 15 cohort studies including 444255 patients from 1625 potentially relevant studies. In the meta-analysis, ovarian cancer risk by endometriosis and clinicopathologic characteristics were evaluated using risk ratio (RR) or standard incidence ratio (SIR), and prognosis was investigated using hazard ratio (HR) with $95 \%$ confidence interval (Cl). Heterogeneity was evaluated using Higgins $I^{2}$ to select fixed-effect $\left(I^{2} \leqslant 50 \%\right)$ or random effects models $\left(I^{2}>50 \%\right)$, and found no publication bias using funnel plots with Egger's test $(P>0.05)$. Furthermore, we performed subgroup analyses based on study design, assessment of endometriosis, histology, disease status, quality of study and adjustment for potential confounding factors to minimise bias.

Results: Endometriosis increased ovarian cancer risk in case-control or two-arm cohort studies (RR, 1.265; 95\% Cl, 1.214-1.318) and single-arm cohort studies (SIR, 1.797; 95\% Cl, 1.276-2.531), which were similar in subgroup analyses. Although progressionfree survival was not different between EAOC and non-EAOC ( $\mathrm{HR}, 1.023 ; 95 \% \mathrm{Cl}, 0.712-1.470)$, EAOC was associated with better overall survival than non-EAOC in crude analyses (HR, 0.778; $95 \% \mathrm{Cl}, 0.655-0.925)$. However, progression-free survival and overall survival were not different between the two groups in subgroup analyses. Stage I-II disease, grade 1 disease and nulliparity were more common in EAOC (RRs, 1.959, 1.319 and 1.327; 95\% Cls, 1.367-2.807, 1.149-1.514 and 1.245-1.415), whereas probability of optimal debulking surgery was not different between the two groups $(\mathrm{RR}, 1.403 ; 95 \% \mathrm{Cl}, 0.915-2.152)$. Furthermore, endometrioid and clear cell carcinomas were more common in EAOC (RRs, 1.759 and 2.606; 95\% Cls, 1.551-1.995 and 2.225-3.053), whereas serous carcinoma was less frequent in EAOC than in non-EAOC (RR, $0.733 ; 95 \% \mathrm{Cl}, 0.617-0.871$ ), and there was no difference in the risk of mucinous carcinoma between the two groups $(\mathrm{RR}, 0.805 ; 95 \% \mathrm{Cl}, 0.584-1.109)$. These clinicopathologic characteristics were also similar in subgroup analyses.

Conclusions: Endometriosis is strongly associated with the increased risk of ovarian cancer, and EAOC shows favourable characteristics including early-stage disease, low-grade disease and a specific histology such as endometrioid or clear cell carcinoma. However, endometriosis may not affect disease progression after the onset of ovarian cancer.

Endometriosis is a common gynecologic disease that affects 3-15\% of premenopausal women and 3-5\% of postmenopausal women (Del Carmen et al, 2003). Furthermore, up to $90 \%$ of reproductive women with chronic pelvic pain or infertility show some degree of endometriosis (Somigliana et al, 2006; Suh et al, 2013). In spite of a common disease in women, the aetiology of endometriosis is still

*Correspondence: Professor YS Song; E-mail: yssong@snu.ac.kr

Received 21 September 2013; revised 31 December 2013; accepted 8 January 2014; published online 11 February 2014

(c) 2014 Cancer Research UK. All rights reserved 0007-0920/14 
uncertain (Bulun, 2009). Moreover, endometriosis is considered as a benign condition and it does not result in a catabolic state like a malignancy, whereas it shares common characteristics of ovarian cancer such as tissue invasion, unrestrained growth, angiogenesis and a decrease in the number of cells undergoing apoptosis.

When compared with other female malignancies such as breast, lung and colon cancers, the incidence of ovarian cancer is relatively low (5.0-9.4 per 100000 women), and it shows the cumulative risk of $0.5-1.0 \%$ globally (Jemal et al, 2011). However, ovarian cancer is known to develop in $0.3-1.6 \%$ of women with endometriosis (Mostoufizadeh and Scully, 1980; Seidman, 1996; Swiersz, 2002), and endometriosis is observed in $4-29 \%$ of patients with ovarian cancer (Somigliana et al, 2006), which suggest the association between endometriosis and ovarian cancer. In addition, the malignant transformation of endometriosis by genetic mutations and altered microenvironments has been suggested in spite of the lack of precise mechanisms (Yamaguchi et al, 2008).

Epidemiologically, endometriosis has been reported to increase the risk of ovarian cancer in some studies (Ness et al, 2000, 2002; Borgfeldt and Andolf, 2004; Modugno et al, 2004; Pearce et al,
2012) that suggest the possibility that endometriosis-associated ovarian cancer (EAOC) may be developed through different mechanisms in comparison with non-EAOC. However, the increased risk was not noted in other studies (Royar et al, 2001; Olson et al, 2002; Brinton et al, 2004; Glud et al, 2004; Terry et al, 2005; Risch et al, 2006; Cunningham et al, 2009; Bodmer et al, 2011; Ness et al, 2011). Moreover, the difference in prognosis between EAOC and non-EAOC patients is still not clear. Some studies have shown better survival in patients with EAOC (Erzen et al, 2001; Melin et al, 2011), whereas it was not different between the two groups in other studies (McMeekin et al, 1995; Komiyama et al, 1999; Orezzoli et al, 2008; Kumar et al, 2011; Cuff and Longacre, 2012; Katagiri et al, 2012). For explaining better prognosis in patients with EAOC, some investigators have reported that they may have favourable characteristics such as young age, early-stage disease, a specific histology such as endometrioid or clear cell carcinoma, low-grade disease and an increase of probability of optimal debulking surgery (McMeekin et al, 1995; Ziogas et al, 2000; Erzen et al, 2001; Orezzoli et al, 2008; Rossing et al, 2008; Kumar et al, 2011; Wang et al, 2013), whereas these

A

Case-control or two-arm cohort studies

Model Study name

$\begin{array}{llll} & \begin{array}{c}\text { Risk } \\ \text { ratio }\end{array} & \begin{array}{c}\text { Lower } \\ \text { limit }\end{array} & \begin{array}{c}\text { Upper } \\ \text { limit }\end{array} \\ \text { Ness } \text { et al, 2000 } & 1.238 & 1.023 & 1.498 \\ \text { Ziogas } \text { et al, 2000 } & 1.251 & 1.094 & 1.431 \\ \text { Royar } \text { et } \text { al, 2001 } & 0.905 & 0.343 & 2.389 \\ \text { Olson } \text { et al, 2002 } & 0.777 & 0.247 & 2.446 \\ \text { Borgfeldt } \text { et al, 2004 } & 1.344 & 1.035 & 1.746 \\ \text { Glud } \text { et al, 2004 } & 1.293 & 0.731 & 2.287 \\ \text { Pike } \text { et al, 2004 } & 1.242 & 1.092 & 1.412 \\ \text { Brinton } \text { et al, 2005 } & 1.690 & 1.277 & 2.236 \\ \text { Terry et al, 2005 } & 1.097 & 0.913 & 1.320 \\ \text { Risch et al, 2006 } & 1.199 & 0.959 & 1.500 \\ \text { Merrit } \text { et al, 2008 } & 1.212 & 1.060 & 1.385 \\ \text { Moorman } \text { et al, 2008 } & 1.325 & 1.143 & 1.535 \\ \text { Rossing et al, 2008 } & 1.331 & 1.091 & 1.625 \\ \text { Cunningham } \text { et al, 2009 } & 1.272 & 0.963 & 1.681 \\ \text { Wu et al, 2009 } & 1.252 & 1.038 & 1.512 \\ \text { Lurie } \text { et al, 2010 } & 1.370 & 1.083 & 1.732 \\ \text { Aris, 2010 } & 1.600 & 1.153 & 2.220 \\ \text { Ness } \text { et al, 2011 } & 1.228 & 0.979 & 1.541 \\ \text { Balogun } \text { et al, 2011 } & 1.440 & 1.125 & 1.843 \\ \text { Vitonis } \text { et al, 2011 } & 1.245 & 1.141 & 1.359 \\ \text { Bodmer } \text { et al, 2011 } & 1.221 & 0.782 & 1.907 \\ \text { Total (summary) } & 1.265 & 1.214 & 1.318\end{array}$

Heterogeneity: $P=0.899 ; I^{2}=0 \%$
Risk ratio and $95 \% \mathrm{Cl}$

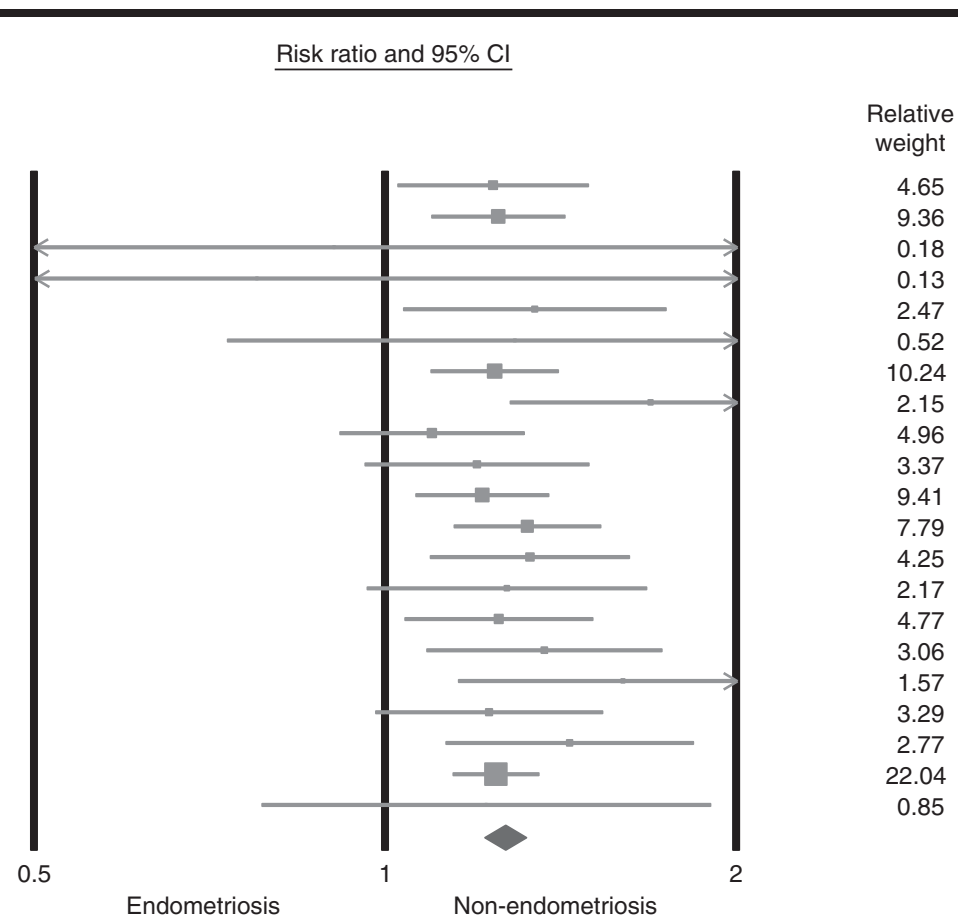

Single-arm cohort studies

B

Model Study name

\begin{tabular}{lrrr}
\hline & $\begin{array}{c}\text { Standard } \\
\text { incidence } \\
\text { ratio }\end{array}$ & $\begin{array}{c}\text { Lower } \\
\text { limit }\end{array}$ & $\begin{array}{c}\text { Upper } \\
\text { limit }\end{array}$ \\
Brinton et al, 1997 & 1.921 & 1.031 & 3.577 \\
Brinton et al, 2004 & 2.500 & 0.904 & 6.911 \\
Melin et al, 2006 & 1.434 & 1.087 & 1.891 \\
Kobayashi et al, 2007 & 5.599 & 2.243 & 13.974 \\
Melin et al, 2007 & 1.370 & 1.056 & 1.778 \\
Total (summary) & 1.797 & 1.276 & 2.531
\end{tabular}

Random Total (summary)

2.531
Risk ratio and $95 \% \mathrm{Cl}$

Relative

$\underline{\text { Standard incidence ratio and } 95 \% \mathrm{Cl}}$ weight

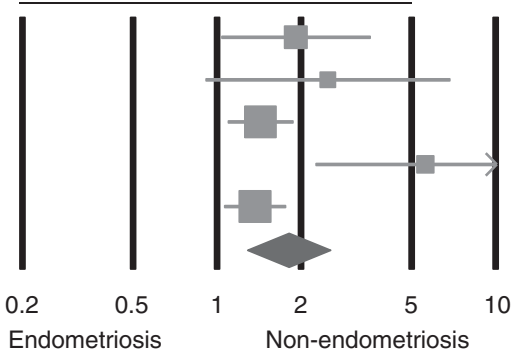

17.18

8.82

31.45

10.36

32.20

Heterogeneity: $P=0.002 ; I^{2}=76.057 \%$

Figure 1. Forest plots for (A) risk ratio with $95 \% \mathrm{Cl}$ in case-control or two-arm cohort studies, and (B) SIR with $95 \% \mathrm{Cl}$ in single-arm cohort studies to assess an increased risk of ovarian cancer by endometriosis. 
findings were not identified in other relevant studies (Komiyama et al, 1999; Lim et al, 2009; Boyraz et al, 2013).

Some pooled analyses or systematic reviews using a small number of case-control or cohort studies suggested the impact of endometriosis on ovarian cancer risk and prognosis (Ness et al, 2002; Modugno et al, 2004; Sayasneh et al, 2011; Pearce et al, 2012), and a recent meta-analysis showed an increased risk of ovarian cancer with histologically verified endometriosis (Heidemann et al, 2014). However, a comprehensive attempt is needed for quantifying ovarian cancer risk in women with endometriosis, and for clarifying prognosis and clinicopathologic characteristics of EAOC when we consider that endometriosis was determined by various methods including self-report, registration from databases and histology in many relevant studies. With the aim of disentangling these intriguing and controversial issues, we performed a meta-analysis using the largest number of relevant studies published up to now.

\section{MATERIALS AND METHODS}

Search strategy and selection criteria. The study was conducted in line with the recommendations from the Preferred Reporting Items for Systematic Reviews and Meta-Analyses (PRISMA) guidelines (Liberati et al, 2009). For the meta-analysis, we searched PubMed, EmBase and the Cochrane Central Register of Controlled Trials (CENTRAL) in the Cochrane Library for relevant studies published online between January 1990 and December 2012. The search terms used were the following: 'ovarian tumor and endometriosis', 'ovarian neoplasm and endometriosis', 'ovarian carcinoma and endometriosis' and 'ovarian cancer and endometriosis'.

We included relevant studies that met the following criteria: (1) epithelial ovarian cancer; (2) case-control or two-arm cohort studies comparing ovarian cancer risk between women with endometriosis and those without endometriosis; (3) single-arm cohort studies comparing ovarian cancer risk between observed and expected events of ovarian cancer in only women with endometriosis; and (4) studies comparing progression-free survival, overall survival and clinicopathologic characteristics between EAOC and non-EAOC patients. However, we excluded studies as follows: (1) review articles; 2) case reports or editorials or letters to the editor not including original data; (3) studies not meeting the selection criteria; and (4) non-English literature.

Selection of studies. Two of the authors (HSK and HHC) independently evaluated potential eligibility of all studies retrieved from the database according to the predetermined selection and exclusion criteria, and the third author (YSS) resolved disagreement between the two authors after discussion. As a result, a total of 1625 studies were identified, and we excluded 89 duplicates and an additional 624 including reviews $(n=294)$, case reports $(n=157)$, non-English literature $(n=145)$, editorials or letters to the editor $(n=25)$, and relevant pooled analyses where we could not obtain individual data from each study, and data from some studies overlapped with those included in the meta-analysis $(n=3)$

Table 1. Subgroup analyses for assessing an increased risk of ovarian cancer by endometriosis

\begin{tabular}{|c|c|c|c|c|c|c|}
\hline & & & & \multicolumn{2}{|c|}{ Heterogeneity } & \multirow[b]{2}{*}{ Model used } \\
\hline Category & $\begin{array}{l}\text { No. of studies } \\
\text { with references }\end{array}$ & RR or SIR & $95 \% \mathrm{Cl}$ & $P$ & $1^{2}$ & \\
\hline \multicolumn{7}{|c|}{ Case-control or two-arm cohort studies } \\
\hline \multicolumn{7}{|l|}{ Study design } \\
\hline $\begin{array}{l}\text { Case-control } \\
\text { Cohort }\end{array}$ & $\begin{array}{r}18 \\
3\end{array}$ & $\begin{array}{l}1.253 \\
1.610\end{array}$ & $\begin{array}{l}1.202-1.307 \\
1.306-1.985\end{array}$ & $\begin{array}{l}0.994 \\
0.435\end{array}$ & $\begin{array}{l}0 \\
0\end{array}$ & $\begin{array}{l}\text { Fixed effect } \\
\text { Fixed effect }\end{array}$ \\
\hline \multicolumn{7}{|c|}{ Assessment of endometriosis } \\
\hline $\begin{array}{l}\text { Self-report } \\
\text { Histology }\end{array}$ & $\begin{array}{r}16 \\
5\end{array}$ & $\begin{array}{l}1.252 \\
1.299\end{array}$ & $\begin{array}{l}1.192-1.314 \\
1.203-1.401\end{array}$ & $\begin{array}{l}0.976 \\
0.200\end{array}$ & $\begin{array}{c}0 \\
33.149\end{array}$ & $\begin{array}{l}\text { Fixed effect } \\
\text { Fixed effect }\end{array}$ \\
\hline \multicolumn{7}{|c|}{ Quality of study (NOS) } \\
\hline $\begin{array}{l}\geqslant 7 \\
<7\end{array}$ & $\begin{array}{r}16 \\
5\end{array}$ & $\begin{array}{l}1.265 \\
1.266\end{array}$ & $\begin{array}{l}1.208-1.324 \\
1.155-1.388\end{array}$ & $\begin{array}{l}0.738 \\
0.801\end{array}$ & $\begin{array}{l}0 \\
0\end{array}$ & $\begin{array}{l}\text { Fixed effect } \\
\text { Fixed effect }\end{array}$ \\
\hline \multicolumn{7}{|c|}{ Adjustment for potential confounding factors } \\
\hline $\begin{array}{l}\text { Three factors }{ }^{a} \\
\text { Eight factors }\end{array}$ & $\begin{array}{l}17 \\
14\end{array}$ & $\begin{array}{l}1.270 \\
1.254\end{array}$ & $\begin{array}{l}1.211-1.332 \\
1.192-1.319\end{array}$ & $\begin{array}{l}0.760 \\
0.961\end{array}$ & $\begin{array}{l}0 \\
0\end{array}$ & $\begin{array}{l}\text { Fixed effect } \\
\text { Fixed effect }\end{array}$ \\
\hline \multicolumn{7}{|c|}{ Single-arm cohort studies } \\
\hline \multicolumn{7}{|c|}{ Assessment of endometriosis } \\
\hline Histology & 4 & 1.463 & $1.233-1.749$ & 0.559 & 0 & Fixed effect \\
\hline \multicolumn{7}{|c|}{ Adjustment for potential confounding factors } \\
\hline $\begin{array}{l}\text { Two factors }^{c} \\
\text { Three factors }^{d}\end{array}$ & $\begin{array}{l}4 \\
3\end{array}$ & $\begin{array}{l}1.507 \\
1.482\end{array}$ & $\begin{array}{l}1.255-1.810 \\
1.231-1.785\end{array}$ & $\begin{array}{l}0.023 \\
0.014\end{array}$ & $\begin{array}{l}68.416 \\
76.514\end{array}$ & $\begin{array}{l}\text { Random effects } \\
\text { Random effects }\end{array}$ \\
\hline \multicolumn{7}{|c|}{ 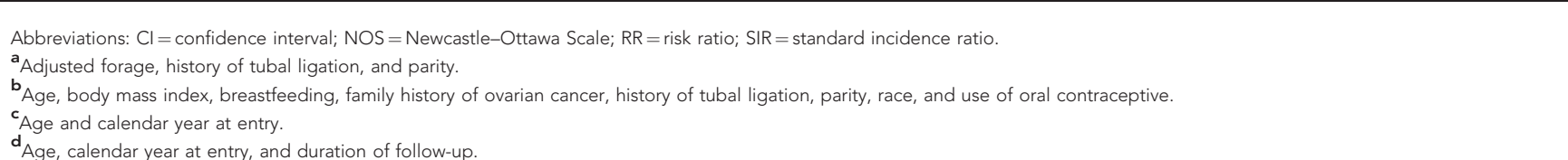 } \\
\hline
\end{tabular}


(Ness et al, 2002; Modugno et al, 2004; Pearce et al, 2012). In addition, we excluded 860 studies because of non-ovarian cancer $(n=640)$, no endometriosis $(n=87)$ and no data about clinicopathologic characteristics, ovarian cancer risk or prognosis $(n=133)$. Furthermore, 17 were also excluded because of no appropriate comparator $(n=16)$, and not enough data to calculate survival $(n=1)$. Finally, 20 case-control (Ness et al, 2000; Ziogas et al, 2000; Royar et al, 2001; Erzen et al, 2001; Borgfeldt and Andolf, 2004; Glud et al, 2004; Pike et al, 2004; Terry et al, 2005; Risch et al, 2006; Merritt et al, 2008; Moorman et al, 2008; Rossing et al, 2008; Cunningham et al, 2009; Wu et al, 2009; Lurie et al, 2010; Balogun et al, 2011; Bodmer et al, 2011; Kumar et al, 2011; Ness et al, 2011; Vitonis et al, 2011) and 15 cohort studies including 444255 patients were included in the meta-analysis (McMeekin et al, 1995; Brinton et al, 1997; Komiyama et al, 1999; Olson et al, 2002; Brinton et al, 2004; Brinton et al, 2005; Melin et al, 2006; Kobayashi et al, 2007; Melin et al, 2007; Orezzoli et al, 2008; Aris, 2010; Melin et al, 2011; Cuff and Longacre, 2012; Katagiri et al, 2012; Wang et al, 2013; Supplementary Figure 1).

Data extraction. Data extraction was also performed by the two authors (HSK and THK), and any discrepancies were addressed by a joint reevaluation of the article with the third author (YSS). The following data were independently extracted from each study for the meta-analysis: the first author; period of enrollment; study design; assessment of endometriosis; age; numbers of women with endometriosis and those without endometriosis in case-control or two-arm cohort studies; numbers of observed and expected events of ovarian cancer, sample size and a number of person-years in single-arm cohort studies; adjustment for potential confounding factors; the International Federation of Gynecology and Obstetrics (FIGO) stage; grade; nulliparity; optimal debulking surgery; histology; numbers of EAOC and non-EAOC patients; and progression-free survival or overall survival. When there was a lack of the relevant data in some studies, we could obtain the formation from some authors whom we contacted or databases suggested from systematic reviews or pooled analyses (Ness et al, 2002; Modugno et al, 2004; Sayasneh et al, 2011; Pearce et al, 2012).

Quality assessment. We assessed the quality of each study using the Newcastle-Ottawa Scale (NOS) for included case-control and cohort studies (Wells et al). The NOS consists of three parameters of quality: selection, comparability and exposure (for a casecontrol study) or outcome (for a cohort study). It assigns a maximum of four points for selection, two points for comparability and three points for exposure or outcome. In the current study, we considered a study with NOS score $\geqslant 7$ as a high-quality study because it has been used as the criteria of high-quality study in spite of no standard criteria (Myung et al, 2009; Castillo et al, 2011). In case-control studies, 15 (75\%) were of high quality with an average NOS score of 6.9 (Supplementary Table 1), and 10 $(66.6 \%)$ showed high quality with an average NOS score of 7.6 in cohort studies (Supplementary Table 2).

Statistical analyses. Dichotomous data eligible in each study were shown as a risk ratio (RR) with its $95 \%$ confidence interval (CI) in case-control or two-arm cohort studies. In the meta-analysis using single-arm cohort studies, standard incidence ratio (SIR), which was computed as the observed number of events divided by the expected number of events in only women with endometriosis, and 95\% CI were calculated. Moreover, we performed survival analyses using the statistical procedure described by Tierney et al (2007). Heterogeneity was assessed using Higgins $I^{2}$ that measures the percentage of total variation across studies that is due to heterogeneity rather than chance (Higgins et al, 2003). An $I^{2}>50 \%$
A Model Study name

$\begin{array}{llccc} & \begin{array}{c}\text { Hazard } \\ \text { ratio }\end{array} & \begin{array}{c}\text { Lower } \\ \text { limit }\end{array} & \begin{array}{c}\text { Upper } \\ \text { limit }\end{array} \\ \text { McMeekin et al, 1995 } & 0.530 & 0.254 & 1.107 \\ \text { Orezzoli et al, 2008 } & 0.770 & 0.313 & 1.896 \\ & \text { Cuff et al, 2012 } & 1.340 & 0.777 & 2.311 \\ & \text { Katagiri et al, 2012 } & 1.800 & 0.710 & 4.562 \\ \text { Fixed } & \text { Total (summary) } & 1.023 & 0.712 & 1.470\end{array}$

.470
Progression-free survival

Hazard ratio and $95 \% \mathrm{Cl}$

Heterogeneity: $P=0.121 ; I^{2}=48.340 \%$
Relative weight

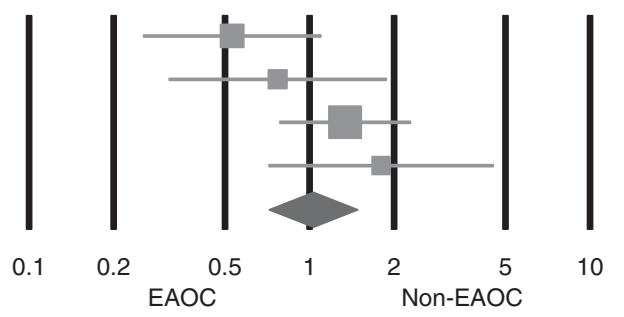

24.28

16.20

44.30

15.22

\begin{tabular}{|c|c|c|c|c|}
\hline \multirow[t]{2}{*}{ Model } & \multicolumn{4}{|l|}{ Study name } \\
\hline & & $\begin{array}{c}\text { Hazard } \\
\text { ratio }\end{array}$ & $\begin{array}{c}\text { Lower } \\
\text { limit }\end{array}$ & $\begin{array}{c}\text { Upper } \\
\text { limit }\end{array}$ \\
\hline & McMeekin et al, 1995 & 1.240 & 0.368 & 4.183 \\
\hline & Komiyama et al, 1999 & 0.620 & 0.168 & 2.285 \\
\hline & Erzen et al, 2001 & 0.560 & 0.360 & 0.871 \\
\hline & Orezzoli et al, 2008 & 0.560 & 0.268 & 1.171 \\
\hline & Kumar et al, 2011 & 0.850 & 0.501 & 1.442 \\
\hline & Melin et al, 2011 & 0.810 & 0.650 & 1.010 \\
\hline & Katagiri et al, 2012 & 1.800 & 0.710 & 4.562 \\
\hline Fixed & Total (summary) & 0.778 & 0.655 & 0.925 \\
\hline
\end{tabular}

Heterogeneity: $P=0.326 ; I^{2}=13.542 \%$

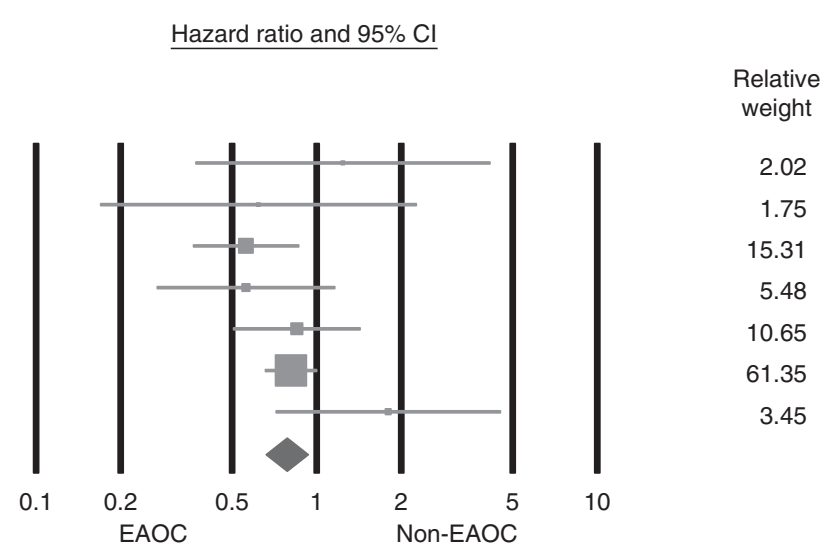

Figure 2. Forest plots for HRs and $95 \% \mathrm{Cls}$ to compare (A) progression-free survival and (B) overall survival between EAOC and non-EAOC. 
was considered to represent substantial heterogeneity, and we used the random effects model using the DerSimonian and Laird method. On the other hand, the fixed effect model using the Mantel-Haenszel method was used in this metaanalysis when the $I^{2}$ was $\leqslant 50 \%$ because it indicated no heterogeneity.

For identifying publication bias, funnel plots were represented that were scatter plots of hazard ratios (HRs) or RRs or SIRs of individual studies on the $\mathrm{X}$ axis against the standard error of the $\log$ HR or $\log$ RR or log SIR of each study on the Y axis. As a result, all funnel plots resembled symmetric inverter funnels that suggested no publication bias in this meta-analysis. Furthermore, we also found no publication bias using Egger's test $(P>0.05)$ (Supplementary Figure 2$)$. For this analysis, we used Comprehensive Meta-analysis Version 2.0 (Biostat Inc., Englewood, NJ, USA), and a $P<0.05$ was considered statistically significant.

\section{RESULTS}

Impact of endometriosis on ovarian cancer risk. Supplementary Tables 3 and 4 show general characteristics of 18 case-control or three two-arm cohort studies including 314421 women with or without endometriosis, and five single-arm cohort studies including 79388 women with endometriosis. Potential confounding factors including age, parity, history of tubal ligation and use of oral contraceptive were adjusted in most of studies. As a result, ovarian cancer risk increased in women with endometriosis when compared with those without endometriosis in case-control or two-arm cohort studies (RR, 1.265; 95\% CI, 1.214-1.318;
Figure 1A), and single-arm cohort studies (SIR, 1.797; 95\% CI, 1.276-2.531; Figure 1B). When we performed subgroup analyses based on study design, assessment of endometriosis, quality of study and adjustment for potential confounding factors, all results also showed that endometriosis was associated with an increased risk of ovarian cancer (Table 1).

Impact of endometriosis on ovarian cancer prognosis. Next, we compared progression-free survival and overall survival between EAOC and non-EAOC patients in eight relevant studies with NOS score $\geqslant 7$ that included 47047 patients, the characteristics of which are summarised in Supplementary Table 5. In most of the studies, patients with EAOC were relatively young in comparison with those with non-EAOC. In terms of survival, there was no difference in progression-free survival between EAOC and nonEAOC (HR, 1.023; 95\% CI, 0.712-1.470; Figure 2A), whereas EAOC was associated with a better overall survival that non-EAOC in crude analyses (HR, 0.778; 95\% CI, 0.655-0.925; Figure 2B). However, there were no differences in progression-free survival and overall survival between EAOC and non-EAOC in subgroup analyses based on histology, assessment of endometriosis, FIGO stage and adjustment for potential confounding factors (Table 2).

Clinicopathologic characteristics in endometriosis-associated ovarian cancer. Finally, we evaluated clinicopathologic characteristics between EAOC and non-EAOC in six cohort studies including 46563 patients and 15 case-control studies including 8417 patients. General characteristics are depicted in Supplementary Table 6. In crude analyses, FIGO stage I-II disease (RR, 1.959; 95\% CI, 1.367-2.807; Figure 3A), grade 1 disease (RR, 1.319; 95\% CI, 1.149-1.514; Figure 3B) and nulliparity (RR, 1.327; 95\% CI, 1.245-1.415; Figure 3C) were more

Table 2. Subgroup analyses for assessing prognosis of endometriosis-associated ovarian cancer

\begin{tabular}{|c|c|c|c|c|c|c|}
\hline & & & & \multicolumn{2}{|c|}{ Heterogeneity } & \multirow[b]{2}{*}{ Model used } \\
\hline Category & $\begin{array}{l}\text { No. of studies } \\
\text { with references }\end{array}$ & HR & $95 \% \mathrm{Cl}$ & $P$ & $1^{2}$ & \\
\hline \multicolumn{7}{|l|}{ Progression-free survival } \\
\hline \multicolumn{7}{|l|}{ Histology } \\
\hline Clear cell carcinoma & 3 & 0.835 & $0.531-1.312$ & 0.150 & 47.280 & Fixed effect \\
\hline \multicolumn{7}{|l|}{ Adjustment for potential confounding factors } \\
\hline $\begin{array}{l}\text { Age } \\
\text { Age, optimal debulking surgery }\end{array}$ & $\begin{array}{l}3 \\
2\end{array}$ & $\begin{array}{l}1.263 \\
1.155\end{array}$ & $\begin{array}{l}0.832-1.916 \\
0.725-1.842\end{array}$ & $\begin{array}{l}0.415 \\
0.303\end{array}$ & $\begin{array}{l}0 \\
5.928\end{array}$ & $\begin{array}{l}\text { Fixed effect } \\
\text { Fixed effect }\end{array}$ \\
\hline \multicolumn{7}{|l|}{ Overall survival } \\
\hline \multicolumn{7}{|l|}{ Assessment of endometriosis } \\
\hline Histology & 6 & 0.730 & $0.553-0.964$ & 0.251 & 24.352 & Fixed effect \\
\hline \multicolumn{7}{|l|}{ FIGO stage } \\
\hline $\begin{array}{l}\text { Early stage (I-II) } \\
\text { Advanced stage (III-IV) }\end{array}$ & $\begin{array}{l}3 \\
3\end{array}$ & $\begin{array}{l}0.753 \\
0.908\end{array}$ & $\begin{array}{l}0.494-1.147 \\
0.590-1.397\end{array}$ & $\begin{array}{l}0.979 \\
0.977\end{array}$ & $\begin{array}{l}0 \\
0\end{array}$ & $\begin{array}{l}\text { Fixed effect } \\
\text { Fixed effect }\end{array}$ \\
\hline \multicolumn{7}{|l|}{ Histology } \\
\hline Clear cell carcinoma & 3 & 0.820 & $0.352-1.911$ & 0.098 & 56.856 & Random effects \\
\hline \multicolumn{7}{|l|}{ Adjustment for potential confounding factors } \\
\hline $\begin{array}{l}\text { Age } \\
\text { Age, grade } \\
\text { Age, grade, platinum-based chemotherapy }\end{array}$ & $\begin{array}{l}6 \\
4 \\
3\end{array}$ & $\begin{array}{l}0.771 \\
0.840 \\
0.966\end{array}$ & $\begin{array}{l}0.647-0.918 \\
0.578-1.221 \\
0.626-1.491\end{array}$ & $\begin{array}{l}0.272 \\
0.267 \\
0.303\end{array}$ & $\begin{array}{l}21.432 \\
24.086 \\
16.295\end{array}$ & $\begin{array}{l}\text { Fixed effect } \\
\text { Fixed effect } \\
\text { Fixed effect }\end{array}$ \\
\hline
\end{tabular}


common in EAOC, whereas there was no difference in probability of optimal debulking surgery between EAOC and non-EAOC (RR, 1.403; 95\% CI, 0.915-2.152; Figure 3D). In subgroup analyses according to study design, assessment of endometriosis, quality of study and adjustment for potential confounding factors, the results were similar except no difference in grade 1 disease in studies with NOS score $<7$ (RR, 1.087; 95\% CI, 0.518-2.280; Table 3).
In terms of histology, crude analyses showed that serous carcinomas were less frequent in EAOC than in non-EAOC (RR, 0.733; 95\% CI, 0.617-0.871; Figure 3E), and there was no difference in the risk of mucinous carcinomas between the two groups (RR, 0.805; 95\% CI, 0.584-1.109; Figure 3F), whereas endometrioid carcinomas (RR, 1.759; 95\% CI, 1.551-1.995; Figure 3G) and clear cell carcinomas (RR, 2.606; 95\% CIs, 2.225-3.053; Figure $3 \mathrm{H}$ ) were more common in

A

Stage I-II disease

\begin{tabular}{|c|c|c|c|c|}
\hline \multirow[t]{2}{*}{ Model } & \multicolumn{4}{|l|}{ Study name } \\
\hline & & $\begin{array}{l}\text { Risk } \\
\text { ratio }\end{array}$ & $\begin{array}{l}\text { Lower } \\
\text { limit }\end{array}$ & $\begin{array}{l}\text { Upper } \\
\text { limit }\end{array}$ \\
\hline & McMeekin et al, 1995 & 1.859 & 1.229 & 2.811 \\
\hline & Komiyama et al, 1999 & 1.100 & 0.748 & 1.618 \\
\hline & Erzen et al, 2001 & 1.980 & 1.656 & 2.369 \\
\hline & Orezzoli et al, 2008 & 1.573 & 1.038 & 2.384 \\
\hline & Kumar et al, 2011 & 1.996 & 1.330 & 2.993 \\
\hline & Wang et al, 2013 & 4.043 & 3.140 & 5.205 \\
\hline Random & Total (summary) & 1.959 & 1.367 & 2.807 \\
\hline
\end{tabular}

Heterogeneity: $P<0.001 ; I^{2}=87.231 \%$

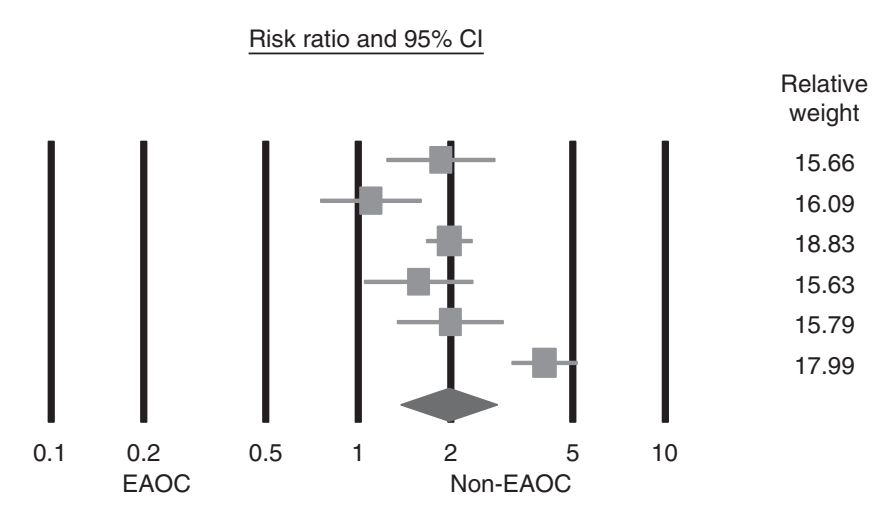

B

Grade 1 disease

Model Study name

$\begin{array}{lrrrr} & & \begin{array}{r}\text { Risk } \\ \text { ratio }\end{array} & \begin{array}{r}\text { Lower } \\ \text { limit }\end{array} & \begin{array}{r}\text { Upper } \\ \text { limit }\end{array} \\ \text { McMeekin et al, 1995 } & 1.091 & 0.733 & 1.624 \\ \text { Ziogas et al, 2000 } & 1.305 & 1.104 & 1.542 \\ \text { Erzen et al, 2001 } & 2.898 & 1.092 & 7.694 \\ \text { Royar et al, 2001 } & 0.911 & 0.182 & 4.553 \\ \text { Glud et al, 2004 } & 1.220 & 0.606 & 2.458 \\ \text { Pike et al, 2004 } & 1.218 & 0.488 & 3.039 \\ \text { Terry et al, 2005 } & 1.283 & 0.398 & 4.130 \\ \text { Risch et al, 2006 } & 2.783 & 0.556 & 13.938 \\ \text { Merrit et al, 2008 } & 1.079 & 0.393 & 2.961 \\ \text { Moorman et al, 2008 } & 0.839 & 0.307 & 2.288 \\ \text { Rossing et al, 2008 } & 3.176 & 1.025 & 9.840 \\ \text { Cunningham et al, 2009 } & 1.166 & 0.062 & 22.046 \\ \text { Balogun et al, 2011 } & 0.592 & 0.035 & 10.002 \\ \text { Kumar et al, 2011 } & 2.545 & 1.086 & 5.967 \\ \text { Ness et al, 2011 } & 1.502 & 0.348 & 6.485 \\ \text { Fixed } & \text { Total (summary) } & 1.319 & 1.149 & 1.514\end{array}$

Heterogeneity: $P=0.734 ; I^{2}=0 \%$
Risk ratio and $95 \% \mathrm{Cl}$

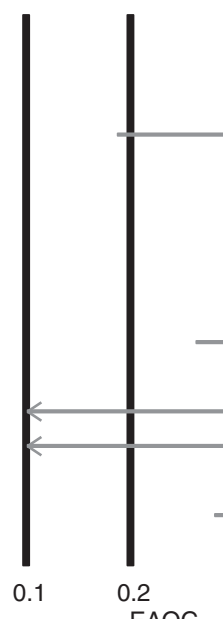

EAOC

Nulliparity

C

\begin{tabular}{|c|c|c|c|c|}
\hline \multirow[t]{2}{*}{ Model } & \multicolumn{4}{|l|}{ Study name } \\
\hline & & $\begin{array}{l}\text { Risk } \\
\text { ratio }\end{array}$ & $\begin{array}{c}\text { Lower } \\
\text { limit }\end{array}$ & $\begin{array}{c}\text { Upper } \\
\text { limit }\end{array}$ \\
\hline & McMeekin et al, 1995 & 2.438 & 1.277 & 4.651 \\
\hline & Komiyama et al, 1999 & 2.200 & 1.135 & 4.266 \\
\hline & Orezzoli et al, 2008 & 1.259 & 0.834 & 1.899 \\
\hline & Melin et al, 2011 & 1.314 & 1.231 & 1.403 \\
\hline Fixed & Total (summary) & 1.327 & 1.245 & 1.415 \\
\hline
\end{tabular}

Heterogeneity: $P=0.073 ; I^{2}=57.002 \%$

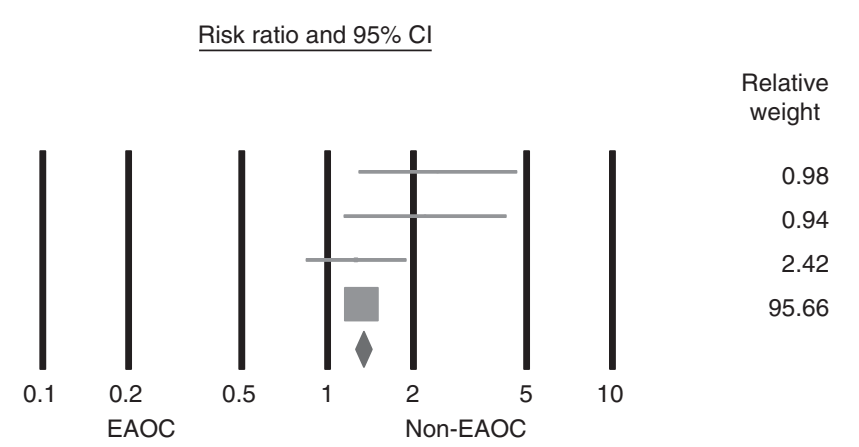

Figure 3. Forest plots for RRs and $95 \% \mathrm{Cls}$ to compare clinicopathologic characteristics including (A) stage I-II disease, (B) grade 1 disease, (C) nulliparity, (D) probability of optimal debulking surgery, and (E) serous, (F) mucinous, (G) endometrioid, and (H) clear cell carcinomas between EAOC and non-EAOC. 
EAOC than in non-EAOC. These findings were more definite in subgroup analyses based on study design, quality of study, assessment of endometriosis and adjustment for potential confounding factors except no difference in the risk of serous carcinoma in studies where endometriosis was assessed with histology (RR, 0.408; 95\% CI, 0.064-2.585; Table 4).

\section{DISCUSSION}

Recent studies suggest the possibility that genetic and nongenetic factors potentially contribute to the neoplastic progression of endometriosis, where the following five typical factors have been suggested to increase ovarian cancer risk by endometriosis: atypical

D

Optimal debulking surgery

\begin{tabular}{|c|c|c|c|c|}
\hline \multirow[t]{2}{*}{ Model } & \multicolumn{4}{|l|}{ Study name } \\
\hline & & $\begin{array}{l}\text { Risk } \\
\text { ratio }\end{array}$ & $\begin{array}{c}\text { Lower } \\
\text { limit }\end{array}$ & $\begin{array}{l}\text { Upper } \\
\text { limit }\end{array}$ \\
\hline & McMeekin et al, 1995 & 1.527 & 1.049 & 2.223 \\
\hline & Komiyama et al, 1999 & 1.120 & 0.813 & 1.544 \\
\hline & Erzen et al, 2001 & 2.925 & 2.324 & 3.682 \\
\hline & Orezzoli et al, 2008 & 1.049 & 0.839 & 1.311 \\
\hline & Kumar et al, 2011 & 1.038 & 0.859 & 1.256 \\
\hline Random & Total (summary) & 1.403 & 0.915 & 2.152 \\
\hline
\end{tabular}

Heterogeneity: $P<0.001 ; I^{2}=93.014 \%$

Risk ratio and $95 \% \mathrm{Cl}$

Relative

weight
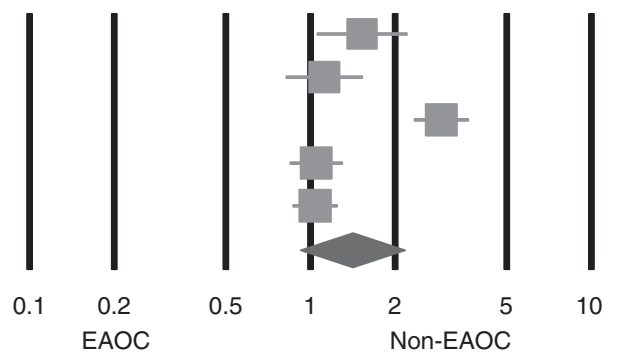

18.65

19.41

20.49

20.57

20.89
E

\begin{tabular}{|c|c|c|c|c|}
\hline \multirow[t]{2}{*}{ Model } & \multicolumn{4}{|l|}{ Study name } \\
\hline & & $\begin{array}{l}\text { Risk } \\
\text { ratio }\end{array}$ & $\begin{array}{c}\text { Lower } \\
\text { limit }\end{array}$ & $\begin{array}{l}\text { Upper } \\
\text { limit }\end{array}$ \\
\hline & Ziogas et al, 2000 & 0.715 & 0.517 & 0.988 \\
\hline & Erzen et al, 2001 & 0.132 & 0.051 & 0.343 \\
\hline & Royar et al, 2001 & 0.770 & 0.154 & 3.841 \\
\hline & Glud et al, 2004 & 0.855 & 0.426 & 1.717 \\
\hline & Pike et al, 2004 & 0.864 & 0.676 & 1.105 \\
\hline & Terry et al, 2005 & 0.707 & 0.528 & 0.947 \\
\hline & Risch et al, 2006 & 0.593 & 0.386 & 0.911 \\
\hline & Merrit et al, 2008 & 0.761 & 0.609 & 0.951 \\
\hline & Moorman et al, 2008 & 0.827 & 0.659 & 1.038 \\
\hline & Rossing et al, 2008 & 0.938 & 0.710 & 1.239 \\
\hline & Cunningham et al, 2009 & 0.578 & 0.358 & 0.933 \\
\hline & Aris, 2010 & 0.438 & 0.232 & 0.827 \\
\hline & Lurie et al, 2010 & 0.781 & 0.509 & 1.197 \\
\hline & Balogun et al, 2011 & 0.620 & 0.341 & 1.129 \\
\hline & Kumar et al, 2011 & 1.832 & 1.287 & 2.607 \\
\hline & Ness et al, 2011 & 0.778 & 0.557 & 1.087 \\
\hline & Wang et al, 2013 & 0.246 & 0.088 & 0.689 \\
\hline Random & Total (summary) & 0.733 & 0.617 & 0.871 \\
\hline
\end{tabular}

Serous carcinoma

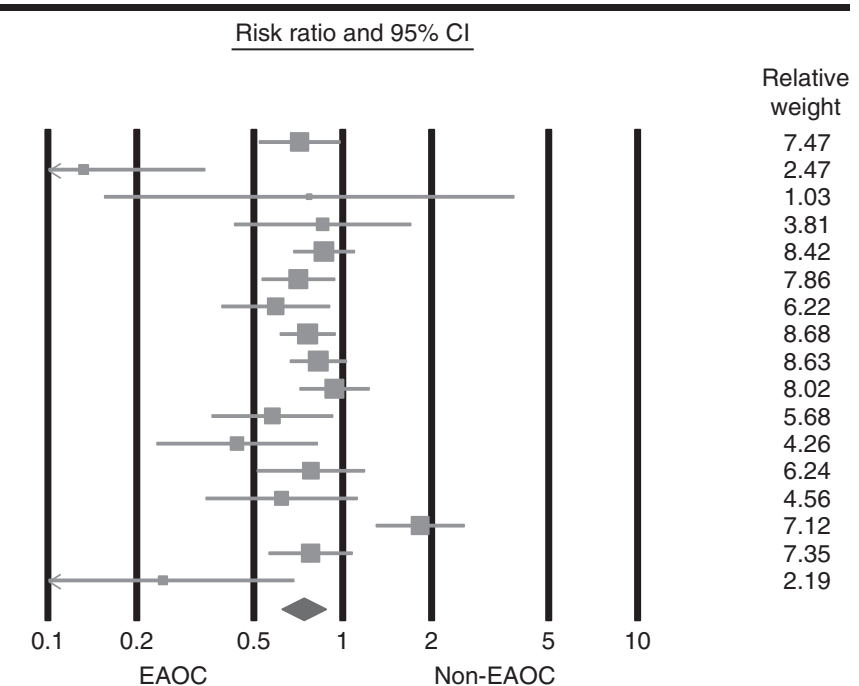

F

\begin{tabular}{|c|c|c|c|c|}
\hline \multirow[t]{2}{*}{ Model } & \multicolumn{4}{|l|}{ Study name } \\
\hline & & $\begin{array}{l}\text { Risk } \\
\text { ratio }\end{array}$ & $\begin{array}{c}\text { Lower } \\
\text { limit }\end{array}$ & $\begin{array}{c}\text { Upper } \\
\text { limit }\end{array}$ \\
\hline & Ziogas et al, 2000 & 0.840 & 0.301 & 2.348 \\
\hline & Erzen et al, 2001 & 0.160 & 0.022 & 1.156 \\
\hline & Royar et al, 2001 & 1.023 & 0.075 & 13.996 \\
\hline & Glud et al, 2004 & 0.586 & 0.039 & 8.781 \\
\hline & Pike et al, 2004 & 0.519 & 0.233 & 1.157 \\
\hline & Terry et al, 2005 & 0.206 & 0.029 & 1.465 \\
\hline & Risch et al, 2006 & 1.305 & 0.395 & 4.308 \\
\hline & Merrit et al, 2008 & 1.252 & 0.506 & 3.097 \\
\hline & Moorman et al, 2008 & 0.645 & 0.204 & 2.044 \\
\hline & Rossing et al, 2008 & 0.174 & 0.011 & 2.837 \\
\hline & Cunningham et al, 2009 & 0.764 & 0.102 & 5.710 \\
\hline & Aris, 2010 & 2.374 & 0.496 & 11.372 \\
\hline & Lurie et al, 2010 & 0.608 & 0.196 & 1.886 \\
\hline & Balogun et al, 2011 & 0.742 & 0.187 & 2.954 \\
\hline & Kumar et al, 2011 & 1.752 & 0.577 & 5.318 \\
\hline & Ness et al, 2011 & 1.085 & 0.340 & 3.461 \\
\hline & Wang et al, 2013 & 0.333 & 0.021 & 5.317 \\
\hline Fixed & Total (summary) & 0.805 & 0.584 & 1.109 \\
\hline
\end{tabular}

Mucinous carcinoma

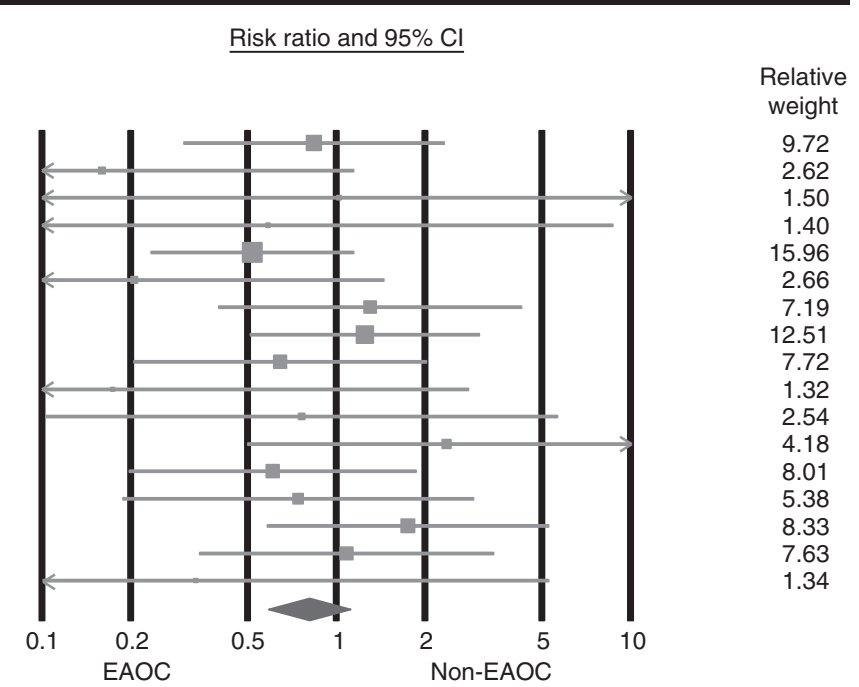

Figure 3. (Continued) 
endometriosis as a precursor of malignancy; genetic alteration in endometrial tissues; heme or free iron-induced oxidative stress; chronic inflammation; and steroid hormones including oestrogen and progesterone (Del Carmen et al, 2003; Somigliana et al, 2006; Mandai et al, 2009; Kokcu, 2011; Munksgaard and Blaakaer, 2012). For supporting the possibility of the malignant transformation of endometriosis, a recent pooled analysis has reported that the association of a history of ES with an increased risk of ovarian cancer may be clear, in particular, for low-grade serous, endometrioid and clear cell carcinoma, showing the consistency with laboratory evidence of related molecular and genetic alterations (Pearce et al, 2012).

However, relevant reviews and pooled analyses have some limitations as follows: first, some case-control or cohort studies include only women with moderate or severe endometriosis that thereby can overestimate ovarian cancer risk. Second, definite information about well-known preventive factors of ovarian cancer such as duration of hormonal agent use, infertility and gynaecologic treatment are missing, although potential confounding factors have been reported to be controlled. Third, hospital- or community-based control groups and interview or self-report without medical records can act as selection or recall bias. Furthermore, different regimen of adjuvant chemotherapy after surgery can also be a limitation for comparing prognosis between EAOC and nonEAOC patients.

Although the meta-analysis could not overcome these limitations completely, and most of include studies did not show the definite relation between ovarian cancer and endometriosis in spite of the suggested criteria for the diagnosis of ovarian cancer arising from endometriosis (Sampson, 1925), it has major advantages as follows. We included the greatest number of relevant studies, and performed subgroup analyses according to study design, assessment of endometriosis, histology, FIGO stage, quality of study and adjustment for potential confounding factors to minimise bias. As a result, we obtained the following meaningful results in the metaanalysis.

First, endometriosis increased ovarian cancer risk by $\sim 27 \%$ in case-control or two-arm cohort studies, and $\sim 80 \%$ in single-arm cohort studies. These findings are consistent with the results from previous reviews (Sayasneh et al, 2011; Pearce et al, 2012; Heidemann et al, 2014). Furthermore, these findings were similar in subgroup analyses to minimise bias, suggesting the epidemiologic evidence than endometriosis may be strongly associated with the increased risk of ovarian cancer. Second, early-stage disease,
G

\begin{tabular}{|c|c|c|c|c|}
\hline \multirow[t]{2}{*}{ Model } & \multicolumn{4}{|l|}{ Study name } \\
\hline & & $\begin{array}{l}\text { Risk } \\
\text { ratio }\end{array}$ & $\begin{array}{c}\text { Lower } \\
\text { limit }\end{array}$ & $\begin{array}{c}\text { Upper } \\
\text { limit }\end{array}$ \\
\hline & Ziogas et al, 2000 & 2.056 & 1.311 & 3.224 \\
\hline & Erzen et al, 2001 & 2.129 & 1.563 & 2.900 \\
\hline & Royar et al, 2001 & 1.061 & 0.077 & 14.539 \\
\hline & Glud et al, 2004 & 0.924 & 0.146 & 5.850 \\
\hline & Pike et al, 2004 & 1.522 & 1.039 & 2.231 \\
\hline & Terry et al, 2005 & 1.599 & 1.087 & 2.351 \\
\hline & Risch et al, 2006 & 1.623 & 0.990 & 2.663 \\
\hline & Merrit et al, 2008 & 1.403 & 0.895 & 2.199 \\
\hline & Moorman et al, 2008 & 1.229 & 0.777 & 1.944 \\
\hline & Rossing et al, 2008 & 1.666 & 1.056 & 2.629 \\
\hline & Cunningham et al, 2009 & 1.508 & 0.741 & 3.066 \\
\hline & Aris, 2010 & 2.456 & 1.295 & 4.658 \\
\hline & Lurie et al, 2010 & 2.197 & 1.362 & 3.545 \\
\hline & Balogun et al, 2011 & 2.188 & 1.135 & 4.218 \\
\hline & Kumar et al, 2011 & 1.878 & 0.767 & 4.598 \\
\hline & Ness et al, 2011 & 0.781 & 0.357 & 1.711 \\
\hline & Wang et al, 2013 & 6.706 & 2.829 & 15.898 \\
\hline Fixed & Total (summary) & 1.759 & 1.551 & 1.995 \\
\hline
\end{tabular}

H

\begin{tabular}{|c|c|c|c|c|}
\hline Model & \multicolumn{4}{|l|}{ Study name } \\
\hline & & $\begin{array}{l}\text { Risk } \\
\text { ratio }\end{array}$ & $\begin{array}{c}\text { Lower } \\
\text { limit }\end{array}$ & $\begin{array}{c}\text { Upper } \\
\text { limit }\end{array}$ \\
\hline & Ziogas et al, 2000 & 2.415 & 1.274 & 4.578 \\
\hline & Erzen et al, 2001 & 2.182 & 0.842 & 5.654 \\
\hline & Royar et al, 2001 & 4.327 & 0.290 & 64.461 \\
\hline & Glud et al, 2004 & 3.244 & 0.943 & 11.162 \\
\hline & Pike et al, 2004 & 2.586 & 1.608 & 4.159 \\
\hline & Terry et al, 2005 & 1.872 & 1.171 & 2.992 \\
\hline & Risch et al, 2006 & 2.061 & 0.996 & 4.266 \\
\hline & Merrit et al, 2008 & 2.023 & 1.208 & 3.387 \\
\hline & Moorman et al, 2008 & 2.529 & 1.592 & 4.018 \\
\hline & Rossing et al, 2008 & 3.308 & 1.656 & 6.608 \\
\hline & Cunningham et al, 2009 & 5.169 & 2.334 & 11.450 \\
\hline & Aris, 2010 & 2.914 & 1.442 & 5.886 \\
\hline & Lurie et al, 2010 & 1.384 & 0.661 & 2.899 \\
\hline & Balogun et al, 2011 & 2.598 & 1.160 & 5.818 \\
\hline & Kumar et al, 2011 & 1.878 & 0.927 & 3.801 \\
\hline & Ness et al, 2011 & 3.905 & 2.244 & 6.798 \\
\hline & Wang et al, 2013 & 7.025 & 3.439 & 14.351 \\
\hline & Total (summary) & & & \\
\hline
\end{tabular}

Risk ratio and $95 \% \mathrm{Cl}$

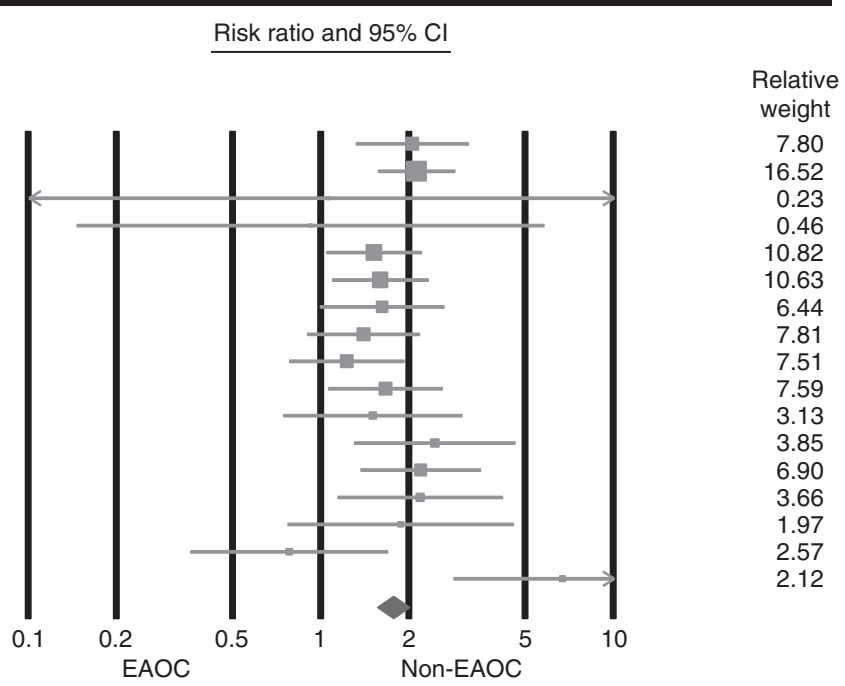

Endometrioid carcinoma

Clear cell carcinoma

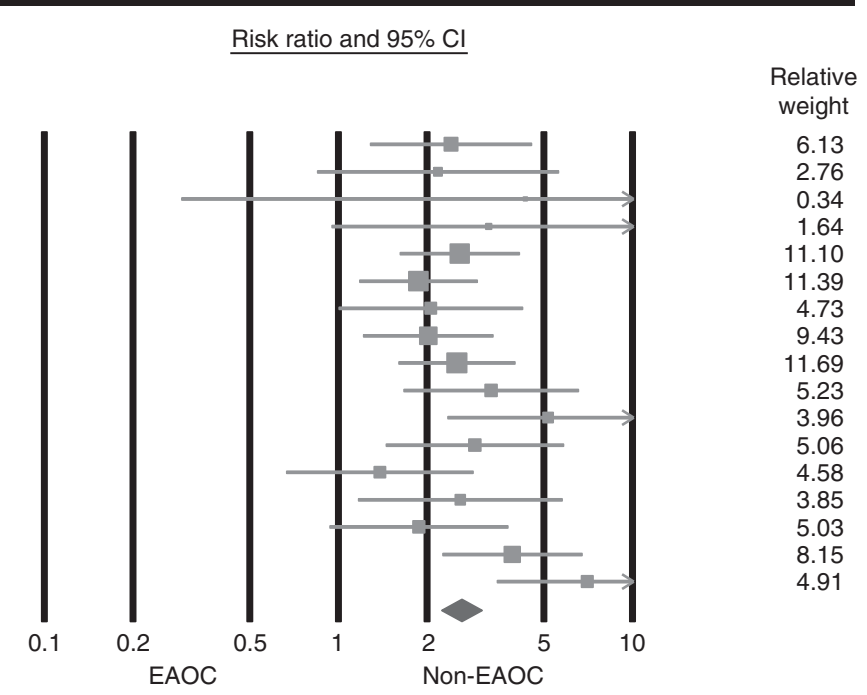

Figure 3. (Continued) 
Table 3. Subgroup analyses for evaluating clinicopathologic characteristics of endometriosis-associated ovarian cancer

\section{Heterogeneity}

\begin{tabular}{|c|c|c|c|c|c|c|}
\hline Category & $\begin{array}{l}\text { No. of studies } \\
\text { with references }\end{array}$ & RR & $95 \% \mathrm{Cl}$ & $P$ & $I^{2}$ & Model used \\
\hline \multicolumn{7}{|c|}{ FIGO stage I-II disease } \\
\hline \multicolumn{7}{|l|}{ Study design } \\
\hline $\begin{array}{l}\text { Case-control } \\
\text { Cohort }\end{array}$ & $\begin{array}{l}2 \\
4\end{array}$ & $\begin{array}{l}1.983 \\
1.920\end{array}$ & $\begin{array}{l}1.683-2.336 \\
1.020-3.616\end{array}$ & $\begin{array}{r}0.973 \\
<0.001\end{array}$ & $\begin{array}{l}0 \\
91.975\end{array}$ & $\begin{array}{l}\text { Fixed effect } \\
\text { Radom effects }\end{array}$ \\
\hline \multicolumn{7}{|c|}{ Adjustment for potential confounding factors } \\
\hline Age & 5 & 1.973 & $1.297-3.003$ & $<0.001$ & 89.656 & Random effects \\
\hline
\end{tabular}

\section{Grade 1 disease}

\begin{tabular}{|c|c|c|c|c|c|c|}
\hline \multicolumn{7}{|l|}{ Study design } \\
\hline Case-control & 14 & 1.354 & $1.169-1.568$ & 0.743 & 0 & Fixed effect \\
\hline \multicolumn{7}{|c|}{ Quality of study (NOS) } \\
\hline$\geqslant 7$ & 11 & 1.328 & $1.155-1.528$ & 0.456 & 0 & Fixed effect \\
\hline$<7$ & 4 & 1.087 & $0.518-2.280$ & 0.963 & 0 & Fixed effect \\
\hline \multicolumn{7}{|c|}{ Assessment of endometriosis } \\
\hline Histology & 3 & 1.801 & $0.898-3.610$ & 0.063 & 63.872 & Random effects \\
\hline Self-report & 12 & 1.303 & $1.121-1.515$ & 0.945 & 0 & Fixed effect \\
\hline \multicolumn{7}{|c|}{ Adjustment for potential confounding factors } \\
\hline Two factors ${ }^{a}$ & 13 & 1.330 & $1.147-1.543$ & 0.858 & 0 & Fixed effect \\
\hline Eight factors ${ }^{\mathbf{b}}$ & 12 & 1.303 & $1.121-1.515$ & 0.945 & 0 & Fixed effect \\
\hline \multicolumn{7}{|l|}{ Nulliparity } \\
\hline \multicolumn{7}{|c|}{ Assessment of endometriosis } \\
\hline Histology & 3 & 1.648 & $1.212-2.241$ & 0.150 & 47.262 & Fixed effect \\
\hline \multicolumn{7}{|c|}{ Adjustment for potential confounding factors } \\
\hline Age & 3 & 1.319 & $1.237-1.407$ & 0.308 & 15.038 & Fixed effect \\
\hline \multicolumn{7}{|c|}{ Optimal debulking surgery } \\
\hline \multicolumn{7}{|l|}{ Study design } \\
\hline Case-control & 2 & 1.739 & $0.630-4.799$ & $<0.001$ & 97.838 & Random effects \\
\hline Cohort & 3 & 1.147 & $0.973-1.352$ & 0.239 & 30.192 & Fixed effect \\
\hline \multicolumn{7}{|c|}{ Adjustment for potential confounding factors } \\
\hline Age & 4 & 1.376 & $0.827-2.290$ & $<0.001$ & 94.729 & Random effects \\
\hline
\end{tabular}

low-grade disease and endometrioid and clear cell carcinomas were strongly associated with EAOC and non-EAOC. Recently, a dualistic model for ovarian carcinogenesis has been suggested. Type I ovarian tumours are clinically indolent and usually present with low-grade carcinoma, showing KRAS, BRAF, ERBB2, PTEN, CTNNB1 and PIK3-CA mutations. These mutations exhibit the continuum of tumour progression between benign cystic neoplasms and the corresponding carcinomas such as endometrioid, clear cell and low-grade serous carcinomas, often through precursor lesions such as ES and borderline tumours (Cho and Shih, 2009). On the other hand, type II ovarian tumours are highly aggressive and almost always present in advanced-stage disease, showing TP53 mutation (Bast et al, 2009). Our meta-analytic results show the epidemiologic evidence that EAOC may have favourable characteristics of type I ovarian tumours. Furthermore, we found that the risk of EAOC increased in relatively young or nulliparous women, and this also suggests the epidemiologic evidence that the retrograde menstruation and activation of oncogenic pathways in eutopic endometrium may permit endometrial tissues to implant and invade on ovarian and peritoneal surfaces that leads to type I ovarian tumours (Bulun, 2009).

In particular, a specific histology such as endometrioid or clear cell carcinoma supports the hypothetical pathogenesis of malignant transformation of endometriosis. In the hypothesis, the carcinogenic process in an oestrogen-rich, progesterone-poor hormonal environment primarily gives rise to endometrioid carcinoma (Ness, 2003; Mandai et al, 2009). Moreover, a highlevel of heme and free iron induces persistent oxidative stress that results in stress-resistant type such as clear cell carcinoma 
Table 4. Subgroup analyses for evaluating histologic types of endometriosis-associated ovarian cancer

\section{Heterogeneity}

\begin{tabular}{|c|c|c|c|c|c|c|}
\hline Category & $\begin{array}{l}\text { No. of studies } \\
\text { with references }\end{array}$ & RR & $95 \% \mathrm{Cl}$ & $P$ & $P^{2}$ & Model used \\
\hline \multicolumn{7}{|c|}{ Serous carcinoma } \\
\hline \multicolumn{7}{|l|}{ Study design } \\
\hline $\begin{array}{l}\text { Case-control } \\
\text { Cohort }\end{array}$ & $\begin{array}{r}15 \\
2\end{array}$ & $\begin{array}{l}0.774 \\
0.371\end{array}$ & $\begin{array}{l}0.654-0.915 \\
0.218-0.642\end{array}$ & $\begin{array}{r}<0.001 \\
0.349\end{array}$ & $\begin{array}{l}66.897 \\
0\end{array}$ & $\begin{array}{l}\text { Random effects } \\
\text { Fixed effect }\end{array}$ \\
\hline \multicolumn{7}{|c|}{ Quality of study (NOS) } \\
\hline $\begin{array}{l}\geqslant 7 \\
<7\end{array}$ & $\begin{array}{r}13 \\
4\end{array}$ & $\begin{array}{l}0.729 \\
0.772\end{array}$ & $\begin{array}{l}0.591-0.900 \\
0.630-0.946\end{array}$ & $\begin{array}{r}<0.001 \\
0.435\end{array}$ & $\begin{array}{l}74.977 \\
0\end{array}$ & $\begin{array}{l}\text { Random effects } \\
\text { Fixed effect }\end{array}$ \\
\hline \multicolumn{7}{|c|}{ Assessment of endometriosis } \\
\hline $\begin{array}{l}\text { Histology } \\
\text { Self-report }\end{array}$ & $\begin{array}{r}3 \\
13\end{array}$ & $\begin{array}{l}0.408 \\
0.776\end{array}$ & $\begin{array}{l}0.064-2.585 \\
0.709-0.851\end{array}$ & $\begin{array}{r}<0.001 \\
0.854\end{array}$ & $\begin{array}{l}94.296 \\
0\end{array}$ & $\begin{array}{l}\text { Random effects } \\
\text { Fixed effect }\end{array}$ \\
\hline \multicolumn{7}{|c|}{ Adjustment for potential confounding factors } \\
\hline $\begin{array}{l}\text { Two factors }{ }^{\mathbf{a}} \\
\text { Eight factors }\end{array}$ & $\begin{array}{l}15 \\
14\end{array}$ & $\begin{array}{l}0.793 \\
0.767\end{array}$ & $\begin{array}{l}0.687-0.916 \\
0.701-0.840\end{array}$ & $\begin{array}{l}0.004 \\
0.685\end{array}$ & $\begin{array}{l}56.276 \\
0\end{array}$ & $\begin{array}{l}\text { Random effects } \\
\text { Fixed effect }\end{array}$ \\
\hline \multicolumn{7}{|c|}{ Mucinous carcinoma } \\
\hline \multicolumn{7}{|l|}{ Study design } \\
\hline $\begin{array}{l}\text { Case-control } \\
\text { Cohort }\end{array}$ & $\begin{array}{r}15 \\
2\end{array}$ & $\begin{array}{l}0.777 \\
1.475\end{array}$ & $\begin{array}{l}0.559-1.080 \\
0.377-5.768\end{array}$ & $\begin{array}{l}0.698 \\
0.227\end{array}$ & $\begin{array}{l}0 \\
31.613\end{array}$ & $\begin{array}{l}\text { Fixed effect } \\
\text { Fixed effect }\end{array}$ \\
\hline \multicolumn{7}{|c|}{ Quality of study (NOS) } \\
\hline $\begin{array}{l}\geqslant 7 \\
<7\end{array}$ & $\begin{array}{r}13 \\
4\end{array}$ & $\begin{array}{l}0.887 \\
0.606\end{array}$ & $\begin{array}{l}0.612-1.285 \\
0.321-1.144\end{array}$ & $\begin{array}{l}0.474 \\
0.934\end{array}$ & $\begin{array}{l}0 \\
0\end{array}$ & $\begin{array}{l}\text { Fixed effect } \\
\text { Fixed effect }\end{array}$ \\
\hline \multicolumn{7}{|c|}{ Assessment of endometriosis } \\
\hline $\begin{array}{l}\text { Histology } \\
\text { Self-report }\end{array}$ & $\begin{array}{r}3 \\
13\end{array}$ & $\begin{array}{l}0.565 \\
0.753\end{array}$ & $\begin{array}{l}0.106-3.001 \\
0.530-1.069\end{array}$ & $\begin{array}{l}0.091 \\
0.900\end{array}$ & $\begin{array}{l}58.373 \\
0\end{array}$ & $\begin{array}{l}\text { Random effects } \\
\text { Fixed effect }\end{array}$ \\
\hline \multicolumn{7}{|c|}{ Adjustment for potential confounding factors } \\
\hline $\begin{array}{l}\text { Two factors }{ }^{a} \\
\text { Eight factors }\end{array}$ & $\begin{array}{l}15 \\
14\end{array}$ & $\begin{array}{l}0.852 \\
0.795\end{array}$ & $\begin{array}{l}0.614-1.181 \\
0.565-1.120\end{array}$ & $\begin{array}{l}0.759 \\
0.826\end{array}$ & $\begin{array}{l}0 \\
0\end{array}$ & $\begin{array}{l}\text { Fixed effect } \\
\text { Fixed effect }\end{array}$ \\
\hline \multicolumn{7}{|c|}{ Endometrioid carcinoma } \\
\hline \multicolumn{7}{|l|}{ Study design } \\
\hline $\begin{array}{l}\text { Case-control } \\
\text { Cohort }\end{array}$ & $\begin{array}{r}15 \\
2\end{array}$ & $\begin{array}{l}1.684 \\
3.886\end{array}$ & $\begin{array}{c}1.479-1.917 \\
1.457-10.360\end{array}$ & $\begin{array}{l}0.611 \\
0.067\end{array}$ & $\begin{array}{l}0 \\
70.206\end{array}$ & $\begin{array}{l}\text { Fixed effect } \\
\text { Random effects }\end{array}$ \\
\hline \multicolumn{7}{|c|}{ Quality of study (NOS) } \\
\hline $\begin{array}{l}\geqslant 7 \\
<7\end{array}$ & $\begin{array}{r}13 \\
4\end{array}$ & $\begin{array}{l}1.788 \\
1.630\end{array}$ & $\begin{array}{l}1.557-2.054 \\
1.210-2.194\end{array}$ & $\begin{array}{l}0.046 \\
0.790\end{array}$ & $\begin{array}{l}43.661 \\
0\end{array}$ & $\begin{array}{l}\text { Fixed effect } \\
\text { Fixed effect }\end{array}$ \\
\hline \multicolumn{7}{|c|}{ Assessment of endometriosis } \\
\hline $\begin{array}{l}\text { Histology } \\
\text { Self-report }\end{array}$ & $\begin{array}{r}3 \\
13\end{array}$ & $\begin{array}{l}2.837 \\
1.595\end{array}$ & $\begin{array}{l}1.417-5.677 \\
1.380-1.843\end{array}$ & $\begin{array}{l}0.043 \\
0.692\end{array}$ & $\begin{array}{l}68.249 \\
0\end{array}$ & $\begin{array}{l}\text { Random effects } \\
\text { Fixed effect }\end{array}$ \\
\hline \multicolumn{7}{|c|}{ Adjustment for potential confounding factors } \\
\hline $\begin{array}{l}\text { Two factors }{ }^{a} \\
\text { Eight factors }{ }^{b}\end{array}$ & $\begin{array}{l}15 \\
14\end{array}$ & $\begin{array}{l}1.634 \\
1.629\end{array}$ & $\begin{array}{l}1.422-1.878 \\
1.414-1.875\end{array}$ & $\begin{array}{l}0.695 \\
0.629\end{array}$ & $\begin{array}{l}0 \\
0\end{array}$ & $\begin{array}{l}\text { Fixed effect } \\
\text { Fixed effect }\end{array}$ \\
\hline \multicolumn{7}{|c|}{ Clear cell carcinoma } \\
\hline \multicolumn{7}{|l|}{ Study design } \\
\hline $\begin{array}{l}\text { Case-control } \\
\text { Cohort }\end{array}$ & $\begin{array}{r}15 \\
2\end{array}$ & $\begin{array}{l}2.454 \\
4.514\end{array}$ & $\begin{array}{l}2.077-2.899 \\
1.905-10.693\end{array}$ & $\begin{array}{l}0.591 \\
0.085\end{array}$ & $\begin{array}{l}0 \\
66.234\end{array}$ & $\begin{array}{l}\text { Fixed effect } \\
\text { Random effects }\end{array}$ \\
\hline \multicolumn{7}{|c|}{ Quality of study (NOS) } \\
\hline $\begin{array}{l}\geqslant 7 \\
<7\end{array}$ & $\begin{array}{r}13 \\
4\end{array}$ & $\begin{array}{l}2.518 \\
3.012\end{array}$ & $\begin{array}{l}2.111-3.003 \\
2.100-4.321\end{array}$ & $\begin{array}{l}0.147 \\
0.500\end{array}$ & $\begin{array}{l}29.680 \\
0\end{array}$ & $\begin{array}{l}\text { Fixed effect } \\
\text { Fixed effect }\end{array}$ \\
\hline \multicolumn{7}{|c|}{ Assessment of endometriosis } \\
\hline $\begin{array}{l}\text { Histology } \\
\text { Self-report }\end{array}$ & $\begin{array}{r}3 \\
13\end{array}$ & $\begin{array}{l}3.118 \\
2.504\end{array}$ & $\begin{array}{l}1.301-7.472 \\
2.103-2.981\end{array}$ & $\begin{array}{l}0.024 \\
0.484\end{array}$ & $\begin{array}{l}73.229 \\
0\end{array}$ & $\begin{array}{l}\text { Random effects } \\
\text { Fixed effect }\end{array}$ \\
\hline \multicolumn{7}{|c|}{ Adjustment for potential confounding factors } \\
\hline $\begin{array}{l}\text { Two factors }{ }^{\mathrm{a}} \\
\text { Eight factors }{ }^{\mathrm{b}}\end{array}$ & $\begin{array}{l}15 \\
14\end{array}$ & $\begin{array}{l}2.486 \\
2.526\end{array}$ & $\begin{array}{l}2.108-2.931 \\
2.132-2.992\end{array}$ & $\begin{array}{l}0.579 \\
0.552\end{array}$ & $\begin{array}{l}0 \\
0\end{array}$ & $\begin{array}{l}\text { Fixed effect } \\
\text { Fixed effect }\end{array}$ \\
\hline
\end{tabular}


(Mandai et al, 2009). Furthermore, genetic mutations in

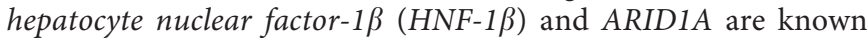
to be related with the onset of endometrioid or clear cell carcinoma from endometriosis (Kato et al, 2006; Wiegand et al, 2010). Nevertheless, we found a relatively low incidence of serous carcinoma in EAOC, and no impact of endometriosis on the risk of mucinous carcinoma.

On the other hand, the recent pooled analysis showed that endometriosis was not associated with the risk of mucinous carcinoma of the ovary (odd ratio (OR), 1.02; 95\% CI, 0.69-1.50), whereas it increased the risk of low-grade serous carcinoma (OR, 2.11; 95\% CI, 1.39-3.20) and did not affect the risk of high-grade serous carcinoma in the recent pooled analysis (OR, 1.13; 95\% CI, 0.97-1.32) (Pearce et al, 2012). These conflicting results on the meta-analysis are because of a number of included studies, study design, quality of study and adjustment for potential confounding factors. When compared with the previous pooled analysis using 13 case-control studies, more studies (15 case-control and two cohort studies) for histology were included in this meta-analysis, and all results were obtained in both crude and subgroup analyses for minimising bias that made the results more persuasive. Furthermore, the result that endometriosis was associated with a lower risk of serous adenocarcinoma is reasonable in this metaanalysis when we considered that endometriosis was related with the increased risk of endometrioid and clear cell carcinomas, and mucinous carcinoma was not associated with endometriosis.

Third, endometriosis did not affect prognosis of ovarian cancer. Although there was no difference in progression-free survival between the two groups, EAOC was associated with better overall survival than non-EAOC in crude analyses. These findings explain why previous studies have suggested better prognosis of EAOC with favourable characteristics including early-stage disease, lowgrade disease and a specific histology up to now (Erzen et al, 2001). However, there were no differences in both progression-free survival and overall survival between the two groups in subgroup analyses based on histology, assessment of endometriosis, disease status and adjustment for potential confounding factors. These findings mean that endometriosis may not affect prognosis of ovarian cancer in spite of favourable characteristics of type I ovarian tumours, and previous studies have also demonstrated no benefit of survival in patients with EAOC when controlled with FIGO stage (McMeekin et al, 1995; Komiyama et al, 1999; Kumar et al, 2011). Moreover, the impact of endometriosis on probability of optimal debulking surgery, the most important prognostic factor in ovarian cancer, was not determined in the meta-analysis, suggesting no benefit of survival in patients with EAOC indirectly.

In conclusion, endometriosis is strongly associated with the increased risk of ovarian cancer risk. Furthermore, favourable factors of EAOC including early-stage disease, low-grade disease and a specific histology such as endometrioid or clear cell carcinoma belong to type I ovarian tumours showing less invasiveness and slow growth, which supports the epidemiologic evidence linking endometriosis to a precursor lesion of ovarian cancer. In spite of favourable characteristics of EAOC, there was no difference in prognosis between EAOC and non-EAOC when adjusted with stage and a specific histology that suggests that endometriosis may not affect the progression after the onset of ovarian cancer.

These results from this meta-analysis suggest the possibility of no difference in the efficacy of primary standard treatment including cytoreductive surgery and adjuvant taxane- and platinum-based chemotherapy between EAOC and non-EAOC. Thus, prospective clinical trials are required to determine the surgical extent to remove endometriosis as well as tumour, and the optimal regimen and cycles of adjuvant chemotherapy based on clinicopathologic characteristics of EAOC for improving its prognosis.

\section{ACKNOWLEDGEMENTS}

We appreciate the help provided by the Medical Research Collaborating Center (MRCC) in Seoul National University Hospital for statistical analyses. This research was supported by grant (no. 04-2012-0890; 03-2012-0170) from the Seoul National University Hospital research fund, the Priority Research Centers program (no. 2009-0093820), Basic Science Research Program (no. 2011-0025394), and the World Class University program (no. R31-2008-000-10056-0) through the National Research Foundation of Korea (NRF) funded by the Ministry of Education, Science and Technology.

\section{CONFLICT OF INTEREST}

The authors declare no conflict of interest.

\section{AUTHOR CONTRIBUTIONS}

HSK conceived and designed the study, selected and interpreted the data and drafted the manuscript; HHC selected the articles; THK retrieved the data; YSS designed the study and revised the manuscript. All authors approved the final version of the manuscript.

\section{REFERENCES}

Aris A (2010) Endometriosis-associated ovarian cancer: a ten-year cohort study of women living in the Estrie Region of Quebec, Canada. J Ovarian Res 3: 2 .

Balogun N, Gentry-Maharaj A, Wozniak EL, Lim A, Ryan A, Ramus SJ, Ford J, Burnell M, Widschwendter M, Gessler SF, Gayther SA, Jacobs IJ, Menon U (2011) Recruitment of newly diagnosed ovarian cancer patients proved challenging in a multicentre biobanking study. J Clin Epidemiol 64: 525-530.

Bast Jr RC, Hennessy B, Mills GB (2009) The biology of ovarian cancer: new opportunities for translation. Nat Rev Cancer 9: 415-428.

Bodmer M, Becker C, Meier C, Jick SS, Meier CR (2011) Use of metformin and the risk of ovarian cancer: a case-control analysis. Gynecol Oncol 123: 200-204.

Borgfeldt C, Andolf E (2004) Cancer risk after hospital discharge diagnosis of benign ovarian cysts and endometriosis. Acta Obstet Gynecol Scand 83: 395-400.

Boyraz G, Selcuk I, Yazıcıoğlu A, Tuncer ZS (2013) Ovarian carcinoma associated with endometriosis. Eur J Obstet Gynecol Reprod Biol 170: 211-213.

Brinton LA, Gridley G, Persson I, Baron J, Bergqvist A (1997) Cancer risk after a hospital discharge diagnosis of endometriosis. Am J Obstet Gynecol 176: $572-579$.

Brinton LA, Lamb EJ, Moghissi KS, Scoccia B, Althuis MD, Mabie JE, Westhoff CL (2004) Ovarian cancer risk associated with varying causes of infertility. Fertil Steril 82: 405-414.

Brinton LA, Sakoda LC, Sherman ME, Frederiksen K, Kjaer SK, Graubard BI, Olsen JH, Mellemkjaer L (2005) Relationship of benign gynecologic diseases to subsequent risk of ovarian and uterine tumors. Cancer Epidemiol Biomarkers Prev 14: 2929-2935.

Bulun SE (2009) Endometriosis. N Engl J Med 360: 268-279.

Castillo JJ, Dalia S, Shum H (2011) Meta-analysis of the association between cigarette smoking and incidence of Hodgkin's Lymphoma. J Clin Oncol 29: 3900-3906.

Cho KR, Shih Ie M (2009) Ovarian cancer. Ann Rev Pathol 4: 287-313.

Cuff J, Longacre TA (2012) Endometriosis does not confer improved prognosis in ovarian carcinoma of uniform cell type. Am J Surg Pathol 36: 688-695.

Cunningham JM, Vierkant RA, Sellers TA, Phelan C, Rider DN, Liebow M, Schildkraut J, Berchuck A, Couch FJ, Wang X, Fridley BL. Ovarian Cancer Association Consortium Gentry-Maharaj A, Menon U, Hogdall E, Kjaer S, Whittemore A, DiCioccio R, Song H, Gayther SA, Ramus SJ, Pharaoh PD, 
Goode EL (2009) Cell cycle genes and ovarian cancer susceptibility: a tagSNP analysis. Br J Cancer 101: 1461-1468.

Del Carmen MG, Smith Sehdev AE, Fader AN, Zahurak ML, Richardson M, Fruehauf JP, Montz FJ, Bristow RE (2003) Endometriosis-associated ovarian carcinoma: differential expression of vascular endothelial growth factor and estrogen/progesterone receptors. Cancer 98: 1658-1663.

Erzen M, Rakar S, Klancnik B, Syrjanen K (2001) Endometriosis-associated ovarian carcinoma (EAOC): an entity distinct from other ovarian carcinomas as suggested by a nested case-control study. Gynecol Oncol 83: $100-108$.

Glud E, Kjaer SK, Thomsen BL, Hogdall C, Christensen L, Hogdall E, Bock JE, Blaakaer J (2004) Hormone therapy and the impact of estrogen intake on the risk of ovarian cancer. Arch Intern Med 164: 2253-2259.

Heidemann LN, Hartwell D, Heidemann CH, Jochumsen KM (2014) The relation between endometriosis and ovarian cancer-a review. Acta Obstet Gynecol Scand 93: 20-31.

Higgins JP, Thompson SG, Deeks JJ, Altman DG (2003) Measuring inconsistency in meta-analyses. BMJ 327: 557-560.

Jemal A, Bray F, Center MM, Ferlay J, Ward E, Forman D (2011) Global cancer statistics. CA Cancer J Clin 61: 69-90.

Katagiri A, Nakayama K, Rahman MT, Rahman M, Katagiri H, Nakayama N, Ishikawa M, Ishibashi T, Iida K, Kobayashi H, Otsuki Y, Nakayama S, Miyazaki K (2012) Loss of ARID1A expression is related to shorter progression-free survival and chemoresistance in ovarian clear cell carcinoma. Mod Pathol 25: 282-288.

Kato N, Sasou S, Motoyama T (2006) Expression of hepatocyte nuclear factor-1beta (HNF-1beta) in clear cell tumors and endometriosis of the ovary. Mod Pathol 19: 83-89.

Kobayashi H, Sumimoto K, Moniwa N, Imai M, Takakura K, Kuromaki T, Morioka E, Arisawa K, Terao T (2007) Risk of developing ovarian cancer among women with ovarian endometrioma: a cohort study in Shizuoka, Japan. Int J Gynecol Cancer 17: 37-43.

Kokcu A (2011) Relationship between endometriosis and cancer from current perspective. Arch Gynecol Obstet 284: 1473-1479.

Komiyama S, Aoki D, Tominaga E, Susumu N, Udagawa Y, Nozawa S (1999) Prognosis of Japanese patients with ovarian clear cell carcinoma associated with pelvic endometriosis: clinicopathologic evaluation. Gynecol Oncol 72 342-346.

Kumar S, Munkarah A, Arabi H, Bandyopadhyay S, Semaan A, Hayek K, Garg G, Morris R, Ali-Fehmi R (2011) Prognostic analysis of ovarian cancer associated with endometriosis. Am J Obstet Gynecol 204(63): e61-e67.

Liberati A, Altman DG, Tetzlaff J, Mulrow C, Gotzsche PC, Ioannidis JP, Clarke M, Devereaux PJ, Kleijnen J, Moher D (2009) The PRISMA statement for reporting systematic reviews and meta-analyses of studies that evaluate health care interventions: explanation and elaboration. $J$ Clin Epidemiol 62: e1-e34.

Lim MC, Lee DO, Kang S, Seo SS, Lee BY, Park SY (2009) Clinical manifestations in patients with ovarian clear cell carcinoma with or without co-existing endometriosis. Gynecol Endocrinol 25: 435-440.

Lurie G, Terry KL, Wilkens LR, Thompson PJ, McDuffie KE, Carney ME, Palmieri RT, Cramer DW, Goodman MT (2010) Pooled analysis of the association of PTGS2 rs5275 polymorphism and NSAID use with invasive ovarian carcinoma risk. Cancer Causes Control 21: 1731-1741.

Mandai M, Yamaguchi K, Matsumura N, Baba T, Konishi I (2009) Ovarian cancer in endometriosis: molecular biology, pathology, and clinical management. Int J Clin Oncol 14: 383-391.

McMeekin DS, Burger RA, Manetta A, DiSaia P, Berman ML (1995) Endometrioid adenocarcinoma of the ovary and its relationship to endometriosis. Gynecol Oncol 59: 81-86.

Melin A, Lundholm C, Malki N, Swahn ML, Sparen P, Bergqvist A (2011) Endometriosis as a prognostic factor for cancer survival. Int $J$ Cancer 129: 948-955.

Melin A, Sparen P, Bergqvist A (2007) The risk of cancer and the role of parity among women with endometriosis. Hum Reprod 22: 3021-3026.

Melin A, Sparen P, Persson I, Bergqvist A (2006) Endometriosis and the risk of cancer with special emphasis on ovarian cancer. Hum Reprod 21: 1237-1242.

Merritt MA, Green AC, Nagle CM, Webb PM. Australian Cancer Study and Australian Ovarian Cancer Study GROUP (2008) Talcum powder, chronic pelvic inflammation and NSAIDs in relation to risk of epithelial ovarian cancer. Int J Cancer 122: 170-176.

Modugno F, Ness RB, Allen GO, Schildkraut JM, Davis FG, Goodman MT (2004) Oral contraceptive use, reproductive history, and risk of epithelial ovarian cancer in women with and without endometriosis. Am J Obstet Gynecol 191: 733-740.

Moorman PG, Calingaert B, Palmieri RT, Iversen ES, Bentley RC, Halabi S, Berchuck A, Schildkraut JM (2008) Hormonal risk factors for ovarian cancer in premenopausal and postmenopausal women. Am J Epidemiol 167: 1059-1069.

Mostoufizadeh M, Scully RE (1980) Malignant tumors arising in endometriosis. Clin Obstet Gynecol 23: 951-963.

Munksgaard PS, Blaakaer J (2012) The association between endometriosis and ovarian cancer: a review of histological, genetic and molecular alterations. Gynecol Oncol 124: 164-169.

Myung SK, Ju W, McDonnell DD, Lee YJ, Kazinets G, Cheng CT, Moskowitz JM (2009) Mobile phone use and risk of tumors: a meta-analysis. J Clin Oncol 27: 5565-5572.

Ness RB (2003) Endometriosis and ovarian cancer: thoughts on shared pathophysiology. Am J Obstet Gynecol 189: 280-294.

Ness RB, Cramer DW, Goodman MT, Kjaer SK, Mallin K, Mosgaard BJ, Purdie DM, Risch HA, Vergona R, Wu AH (2002) Infertility, fertility drugs, and ovarian cancer: a pooled analysis of case-control studies. Am J Epidemiol 155: 217-224.

Ness RB, Dodge RC, Edwards RP, Baker JA, Moysich KB (2011) Contraception methods, beyond oral contraceptives and tubal ligation, and risk of ovarian cancer. Ann Epidemiol 21: 188-196.

Ness RB, Grisso JA, Cottreau C, Klapper J, Vergona R, Wheeler JE, Morgan M, Schlesselman JJ (2000) Factors related to inflammation of the ovarian epithelium and risk of ovarian cancer. Epidemiology 11: 111-117.

Olson JE, Cerhan JR, Janney CA, Anderson KE, Vachon CM, Sellers TA (2002) Postmenopausal cancer risk after self-reported endometriosis diagnosis in the Iowa Women's Health Study. Cancer 94: 1612-1618.

Orezzoli JP, Russell AH, Oliva E, Del Carmen MG, Eichhorn J, Fuller AF (2008) Prognostic implication of endometriosis in clear cell carcinoma of the ovary. Gynecol Oncol 110: 336-344.

Pearce CL, Templeman C, Rossing MA, Lee A, Near AM, Webb PM, Nagle CM, Doherty JA, Cushing-Haugen KL, Wicklund KG, Chang-Claude J, Hein R, Lurie G, Wilkens LR, Carney ME, Goodman MT, Moysich K, Kjaer SK, Hogdall E, Jensen A, Goode EL, Fridley BL, Larson MC, Schildkraut JM, Palmieri RT, Cramer DW, Terry KL, Vitonis AF, Titus LJ, Ziogas A, Brewster W, Anton-Culver H, Gentry-Maharaj A, Ramus SJ, Anderson AR, Brueggmann D, Fasching PA, Gayther SA, Huntsman DG, Menon U, Ness RB, Pike MC, Risch H, Wu AH, Berchuck A. Ovarian Cancer Association Consortium (2012) Association between endometriosis and risk of histological subtypes of ovarian cancer: a pooled analysis of case-control studies. Lancet Oncol 13: 385-394.

Pike MC, Pearce CL, Peters R, Cozen W, Wan P, Wu AH (2004) Hormonal factors and the risk of invasive ovarian cancer: a population-based case-control study. Fertil Steril 82: 186-195.

Risch HA, Bale AE, Beck PA, Zheng W (2006) PGR + 331A/G and increased risk of epithelial ovarian cancer. Cancer Epidemiol Biomarkers Prev 15: 1738-1741.

Rossing MA, Cushing-Haugen KL, Wicklund KG, Doherty JA, Weiss NS (2008) Risk of epithelial ovarian cancer in relation to benign ovarian conditions and ovarian surgery. Cancer Causes Control 19: 1357-1364.

Royar J, Becher H, Chang-Claude J (2001) Low-dose oral contraceptives: protective effect on ovarian cancer risk. Int J Cancer 95: 370-374.

Sampson JA (1925) Endometrial carcinoma of the ovary, arising in endometrial tissue in that organ. Arch Surg 10: 1-72.

Sayasneh A, Tsivos D, Crawford R (2011) Endometriosis and ovarian cancer: a systematic review. ISRN Obstet Gynecol 2011: 140310.

Seidman JD (1996) Prognostic importance of hyperplasia and atypia in endometriosis. Int J Gynecol Pathol 15: 1-9.

Somigliana E, Vigano P, Parazzini F, Stoppelli S, Giambattista E, Vercellini P (2006) Association between endometriosis and cancer: a comprehensive review and a critical analysis of clinical and epidemiological evidence. Gynecol Oncol 101: 331-341.

Suh DH, Kim JW, Kim K, Kim HJ, Lee KH (2013) Major clinical research advances in gynecologic cancer in 2012. J Gynecol Oncol 24: 66-82.

Swiersz LM (2002) Role of endometriosis in cancer and tumor development. Ann NY Acad Sci 955: 281-292.

Terry KL, De Vivo I, Titus-Ernstoff L, Shih MC, Cramer DW (2005) Androgen receptor cytosine, adenine, guanine repeats, and haplotypes in relation to ovarian cancer risk. Cancer Res 65: 5974-5981. 
Tierney JF, Stewart LA, Ghersi D, Burdett S, Sydes MR (2007) Practical methods for incorporating summary time-to-event data into metaanalysis. Trials 8: 16 .

Vitonis AF, Titus-Ernstoff L, Cramer DW (2011) Assessing ovarian cancer risk when considering elective oophorectomy at the time of hysterectomy. Obstet Gynecol 117: 1042-1050.

Wang S, Qiu L, Lang JH, Shen K, Yang JX, Huang HF, Pan LY, Wu M (2013) Clinical analysis of ovarian epithelial carcinoma with coexisting pelvic endometriosis. Am J Obstet Gynecol 208: 413e1-413e5.

Wei JJ, William J, Bulun S (2011) Endometriosis and ovarian cancer: a review of clinical, pathologic, and molecular aspects. Int J Gynecol Pathol 30: 553-568.

Wells GA, Shea B, O'Connell D, Peterson J, Welch V, Losos M, Tugwell P. The Newcastle-Ottawa Scale (NOS) for assessing the quality of nonrandomised studies in meta-analyses. http://www.ohri.ca/programs/ clinical_epidemiology/oxford.asp.

Wiegand KC, Shah SP, Al-Agha OM, Zhao Y, Tse K, Zeng T, Senz J, McConechy MK, Anglesio MS, Kalloger SE, Yang W, Heravi-Moussavi A, Giuliany R, Chow C, Fee J, Zayed A, Prentice L, Melnyk N, Turashvili G, Delaney AD, Madore J, Yip S, McPherson AW, Ha G, Bell L, Fereday S, Tam A, Galletta L, Tonin PN, Provencher D, Miller D, Jones SJ, Moore RA, Morin GB, Oloumi A, Boyd N, Aparicio SA, IeM Shih, Mes-Masson AM, Bowtell DD, Hirst M, Gilks B, Marra MA, Huntsman DG (2010) ARID1A mutations in endometriosis-associated ovarian carcinomas. $N$ Engl J Med 363: 1532-1543.

Wu AH, Pearce CL, Tseng CC, Templeman C, Pike MC (2009) Markers of inflammation and risk of ovarian cancer in Los Angeles County. Int J Cancer 124: 1409-1415.

Yamaguchi K, Mandai M, Toyokuni S, Hamanishi J, Higuchi T, Takakura K, Fujii S (2008) Contents of endometriotic cysts, especially the high concentration of free iron, are a possible cause of carcinogenesis in the cysts through the iron-induced persistent oxidative stress. Clin Cancer Res 14: $32-40$

Ziogas A, Gildea M, Cohen P, Bringman D, Taylor TH, Seminara D, Barker D, Casey G, Haile R, Liao SY, Thomas D, Noble B, Kurosaki T, Anton-Culver H (2000) Cancer risk estimates for family members of a population-based family registry for breast and ovarian cancer. Cancer Epidemiol Biomarkers Prev 9: 103-111.

This work is published under the standard license to publish agreement. After 12 months the work will become freely available and the license terms will switch to a Creative Commons AttributionNonCommercial-Share Alike 3.0 Unported License.

Supplementary Information accompanies this paper on British Journal of Cancer website (http://www.nature.com/bjc) 